\title{
Identification Poverty in Semarang City
}

\author{
Voni Hardila Iswari Derlauw; Sri Suwitri \\ Public Administration Doctoral Program, Faculty of Social and Political Science \\ Diponegoro University \\ Semarang, Indonesia \\ (Office Email:prodidap@gmail.com)
}

\begin{abstract}
Poverty is problems in Indonesia until now unresolved. The city of Semarang is the town of the with a poverty rate was higher than other cities in Central Java. To reduce poverty in Semarang city the government issued regional regulation no. 4 years 2008 about poverty reduction in order to accelerate the decline in the number of poor people. But poverty rate in Semarang city not dropped significantly after the regional regulations No. 4 years 2008. Due to the large number poverty by study komparasi the qualitative study will be identified the number of poor people within the city of Semarang before and after the introduction regional regulation No. 4 years 2008 and identified the cause of poverty rate in Semarang city not dropped significantly.
\end{abstract}

Keywords—poverty; implementation; regional regulations

\section{InTRODUCTION}

The city of Semarang have poverty problems serious enough , namely by into poverty rate contributors the highest in central java. The poverty rate of Semarang city from year to year increased significantly. To solve the problem of poverty, the government the city of Semarang issue Regional Regulations, based on Law No.16 of action in 1950 on the establishment of a large city area within the boundaries of the province of East Java, Central Java, West Java and Yogyakarta special region; Law number 10 of 2004 on the establishment of legislation ( the republic of Indonesia Official Gazette 2004 No. 53, additional sheets republic of Indonesia No. 4389 ); Law No. 32 Year 2004 regarding Regional Government (State Gazette of the Republic of Indonesia Year 2004 No. 125; Act No. 33 of 2004 on Financial Balance between the Central Government and Local Government; Act No. 40 of 2004 on National Social Security System; Regulations President No. 54 Year 2005 on Poverty Reduction Coordination team; Presidential Decree No. 1 of 2007 on Ratification, promulgation and dissemination of legislation; Regional Regulation of Semarang No. 11 of 2006 on Regional Financial Management; Regional Regulation of Semarang No. 4 Year 2008 on Poverty Reduction. But after the publication of regional Regulation of poverty to this day, Semarang city poverty rate is still relatively high and did not decline significantly. Theory of policy implementation of Merilee S. Grindle (1980) cited (Subarsono , 2012: 93-94) which states that the implementation of the policy can be said to be successful if the policy has been able to achieve the desired objectives and policy implementation theory of Van Meter and Van Horn (1975) cited by (Wahab, 2008:65) which states that the standards and objectives must be clear and measurable policy because if the standard and vague policy objectives, it will easily lead to conflict between the agents so that the implementation does not go smoothly. From the description it can be seen that the regulations can not achieve their goals if there is no accurate data identified and the the accuracy of target groups. Data on the number of poor people in the city of Semarang in each SKPD different, because SKPD not have the accuracy of indicators to identify the poor and they do not have the coordination to synchronize the data to be published. Inaccurate data available in each SKPD cause the policy can not be precisely targeted so that implementation can not achieve the objectives of the policy.

\section{Theoretical Framework AND Methods}

This research using qualitative research methods to a comparative study before and after the issuance of Regional Regulation No. 4 years 2008, the found indicator inaccuracies in identify data and target groups. Technique data analysis in this research follow the concept given Miles and Huberman and Saldana ( 2014: 33 ), : condensation data, presentation of data and verification of data.

\section{RESUlts AND DiscusSION}

The poverty rate of before and after the region regulation on poverty reduction are still remains the same, in the sense that the poverty rate in the city of Semarang is still high compared to other cities in Central Java.

\begin{tabular}{|} 
TABLE I. THE RATIO OF POVERTY IN SEMARANG CITY \\
\begin{tabular}{|r|c|c|c|}
\hline Description & Years & $\begin{array}{c}\text { The number of poor } \\
\text { people }\end{array}$ & $\begin{array}{c}\text { Percentag } \\
\text { e }\end{array}$ \\
\hline Before the region regulations on poverty \\
reduction
\end{tabular} & 2005 & 94.246 & $6,64 \%$ \\
\cline { 2 - 4 } & 2006 & 246.448 & $17,19 \%$ \\
\cline { 2 - 4 } & 2007 & 306.700 & $21,08 \%$ \\
\cline { 2 - 4 } & 2008 & 491.747 & $33,19 \%$ \\
\hline \hline & & & \\
\hline after the region regulations on & & & \\
poverty reduction & 2009 & 398.009 & $25,95 \%$ \\
\cline { 2 - 4 } & 2010 & 343.647 & $22.08 \%$ \\
\cline { 2 - 4 } & 2011 & 448.398 & $28,28 \%$ \\
\cline { 2 - 4 } & 2012 & 414.483 & $25,42 \%$ \\
\cline { 2 - 4 } & 2013 & 373.978 & $22,73 \%$ \\
\cline { 2 - 4 } & 2014 & 385.941 & $23,19 \%$ \\
\cline { 2 - 4 } & 2015 & 367.848 & $20,73 \%$ \\
\hline
\end{tabular}

It can be seen that the poverty rate from year to year has increased significantly. The number of poor people in the city of Semarang in 2005 reached 94,246 or equivalent to $6.64 \%$ of the total poor population of Semarang. In 2006 the number of poor people Semarang be 246,448 or $17.19 \%$, which means that the poverty rate in the city of Semarang increase is very high at $10.55 \%$. In 2007 the poverty rate in the city of 
Semarang also increased by $3.89 \%$ from $17.19 \%$ to $21.08 \%$. The increase in the poverty rate also happen to occur in 2008 , the amount of poverty in the city of Semarang be 491,747 of the population of the city of Semarang, or an increase of 12.11 $\%$ from the previous year. After the Regional Regulation on poverty in 2009 the poverty rate in the city of Semarang has decreased by $7.23 \%$ from the previous year. In 2010 the poverty rate in the city of Semarang also decreased by $3.87 \%$, but in 2011 the poverty rate in the city of Semarang, a significant increase of $6.2 \%$ from the previous amount, an increase of 104751 inhabitants. In 2012 the number of poor people in the city of Semarang reached 414,483 people, and in 2013 the number of poor families in the city of Semarang decreased to 373,978 inhabitants which shows that the percentage of poverty in the city of Semarang reached 22.73 $\%$. In 2014 the number of poor people amounted to 385,941 Semarang or experienced an increase from the previous year amounted to 373,978. Figures percentage of Semarang in 2015 amounted to $20.73 \%$, which have the sense that the number of poor people of Semarang has decreased from the previous year. From that analysis it can be seen that the poverty in the city of Semarang has increased and decreased after the publication of regional regulations, is not in accordance with the objectives of poverty reduction policies to accelerate the reduction of the number of poor people in the city of Semarang. There are two things that lead to poverty reduction is not maximized, namely :

\section{A. Identification of the Poor}

Poverty data in each SKPD involved in overcoming poverty is different, because the data from BPS and Bappeda different. Poor data collection between BPS and Bappeda have different mechanisms mainly indicators by 14 aspect (BPS) and 7 aspects (Bappeda). Differences in the time span between data collection BPS and Bappeda also can lead to different results. BPS collects data de facto, that if it looks poor will be inserted without stressing these people live in the city of Semarang or not and also BPS cut data is generated, the overall result is a $40 \%$ bottom are reported, while Bappeda put poor people ID card Semarang and Bappeda not cut data generated. For example in 2011 BPS recorded the number of poor people amounted to 88.453 residents of Semarang while Bappeda of 448.398 people, where there is a difference in the number of poor people is very high, the difference between the difference of up to 359.945 inhabitants. Every SKPD related poverty reduction policies using data from BPS and Bappeda led to its implementation is not running smoothly.

\section{B. Not Right on Target}

The assistance provided for overcoming poverty can not cover all the citizens of poor in semarang city because of the absence of synchronization data on the number of poor people. Because of differences in data, a lot of poor people who are not enrolled as a group of recipients. To overcome the government of Semarang allowing people to using SKTM to receive assistance from the government. But the use of SKTM often abused use by the community. The emergence of those who should not feasible and really need sktm, but it could have SKTM, because the urban villages which have not yet selective the issuing of SKTM. Can be concluded that assistance who should be given to the poor to reduce the poverty number not appropriate, even assistance provided by the government did not in accordance with required by people recipient resulting in assistance distributed be unused.

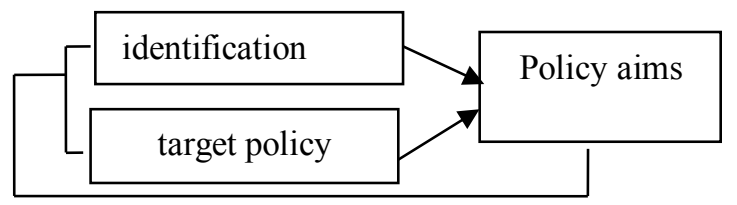

\section{CONCLUSION}

The poverty rate in the city of Semarang before and after the Regional Regulation on poverty reduction is still relatively high. The purpose of regional regulations to accelerate poverty reduction still can not be achieved because of poverty is still increasing and decreasing every year. The cause of the implementation of the regulation can not achieve the goal is the identification of the poor, the government does not have the poverty indicators to identify the data on the poor. Indicators between BPS and Planning Agency as the agency to collect data about poor people differently, BPS uses 14 BAPPEDA aspect while using seven aspects to identify the poor that result in differences are quite high. Data used to provide different support poverty reduction resulted aid is not well targeted. Many poor people have not been able to feel the support of the government and many citizens who receive no assistance as needed .

\section{RECOMMENDATIONS}

$A$. Have the same indicators between Bappeda and bps in identifying the poor.

$B$. Training for the implementor in identifying poor residents and drafting assistance in order to be right on target.

\section{REFERENCES}

[1] Bappeda Kota Semarang Tahun 2015

[2] Derlauw, Voni Hardila Iswari. 2016. Implementasi Penanggulangan Kemiskinan Kota Semarang (Kajian Peraturan Daerah Kota Semarang No. 4 Tahun 2008 tentang Penanggulangan Kemiskinan). Skripsi : Universitas Diponegoro

[3] Miles, Metthew B, A. Michael Huberman and Johnny Saldana.(2014). Qualitative Data Analysis, A Methods Sourcebook, (3 ${ }^{\text {th }}$ Ed.). Sage Publications, Inc.

[4] Subarsono, AG. (2005). Analisis Kebijakan Publik. Yogyakarta :PustakaPelajar.

[5] Wahab, Solichin Abdul. (2005). Analisis Kebijaksanaan Dari Formulasi Ke Impementasi Kebijaksanaan Negara. Jakarta :BumiAksara 